\title{
The Prognostic Significant of Tumor Budding, Tumor Stroma Ratio and Tumor-Infiltrating Lymphocytes in Gallbladder Adenocarcinoma
}

\section{Safra Kesesi Adenokarsinomunda Tümör Tomurcuklanması, Tümör Stroma Oranı ve Tümörü İnfiltre Eden Lenfositlerin Prognostik Önemi}

\author{
@ilke Evrim Seçinti', @Didar Gürsoy', @Tümay Özgür', @Emre Dirican², @Muhyittin Temiz ${ }^{3}$ \\ 'Hatay Mustafa Kemal University, Faculty of Medicine, Department of Pathology, Hatay, Turkey \\ ${ }^{2}$ Hatay Mustafa Kemal University Faculty of Medicine, Department of Biostatistics Hatay, Turkey \\ ${ }^{3}$ Hatay Mustafa Kemal University, Faculty of Medicine, Department of General Surgery, Hatay, Turkey
}

\begin{abstract}
Aim: Tumor microenvironment plays an important role in onset and progression of the cancer. Tumor budding (TB), tumor stroma and tumorinfiltrating lymphocytes are component of the tumor microenvironment. It was aim to determine the relationship of TB, tumor stroma ratio (TSR) and tumor-infiltrating lymphocytes (TILs) with clinicopathological prognostic parameters in gallbladder adenocarcinoma.

Material and Method: Thirty cholecystectomy cases that were diagnosed as adenocarcinoma between 2010 and 2020, that did not receive neoadjuvant therapy and of which archive slides could be accessed, were included in the study. TB, TSR and TILs were evaluated. A $p<0.05$ value was statistically significant.

Results: High TB score was significantly associated with higher histological grade $(p=0.008)$, higher $p T$ stage, lymphovascular invasion (LVI) $(p=0.038)$, lymph node metastasis $(p=0.046)$ and distant metastasis $(p=0.036)$. Patients with high TB scores had a shorter overall survival $(p<0.001)$. In the high TILs group, lower histological grade $(p=0.004)$, less LVI $(p=0.029)$, fewer distant metastases $(p=0.021)$ and lower TSR $(p=0.008)$ were detected. Increased TSR was associated with higher histological grade $(p=0.015)$ and increased distant metastasis $(p=0.013)$. There was no significant effect of TSR on overall survival $(p=0.239)$.

Conclusion: TB can be used as a new prognostic biomarker in gallbladder cancers due to its simple and low cost to determine and also its effectiveness in determining the prognosis. We have concluded that it is early to recommend TILs and TSR as the prognostic indicators in gallbladder cancers. In the future, further studies can be conducted on a larger number of gallbladder cancer cases with a multicenter participation to clarify the prognostic value of TILs and TSR.
\end{abstract}

Keywords: Gallbladder cancer, prognosis, stroma, tumor budding, tumorinfiltrating lymphocyte,

\section{Öz}

Amaç: Tümör mikroçevresi kanserin başlangııında ve ilerlemesinde önemli rol oynar. Tümör tomurcuklanması (TB), tümör stroması ve tümörü infiltre eden lenfositler, tümör mikroçevresinin bileşenleridir. Bu çalışmada safra kesesi adenokarsinomunda TB, tümör stroma oranı (TSR) ve tümörü infiltre eden lenfositlerin (TILs) klinikopatolojik prognostik parametrelerle ilişkisinin belirlenmesi amaçlandı.

Gereç ve Yöntem: 2010-2020 yılları arasında adenokarsinom tanısı alan, neoadjuvan tedavi almayan ve arşiv preparatlarına ulaşılabilen 30 kolesistektomi olgusu çalışmaya dahil edildi. TB, TSR ve TILs değerlendirildi. $p<0.05$ değeri istatistiksel olarak anlamlı kabul edildi.

Bulgular:YüksekTB skoru, daha yüksek histolojik derece $(p=0,008)$, daha yüksek pT evresi, lenfovasküler invazyon (LVI) ( $p=0,038)$, lenf nodu metastazı $(p=0,046)$ ve uzak metastaz $(p=0,036)$ ile anlamlı ilişkiliydi. TB skoru yüksek olan hastaların genel sağkalım süreleri daha kısaydı $(p<0,001)$. Yüksek TILs grubunda, daha düşük histolojik derece $(p=0,004)$, daha az LVI $(p=0,029)$, daha az uzak metastaz $(p=0,021)$ ve daha düşük TSR ( $p=0,008)$ saptandı. Yüksek TSR, daha yüksek histolojik derece $(p=0,015)$ ve artan uzak metastaz $(p=0,013)$ ile ilişkilendirildi. TSR'nin genel sağkalım üzerinde anlamlı bir etkisi yoktu $(p=0,239)$.

Sonuç: TB, hem belirlenmesi basit ve düşük maliyeti olması nedeniyle hem de prognozu belirlemedeki etkinliği nedeniyle safra kesesi kanserlerinde yeni bir prognostik biyobelirteç olarak kullanılabilir. Safra kesesi kanserlerinde prognostik göstergeler olarak TILs ve TSR'yi önermek için erken olduğu kanaatindeyiz. Gelecekte, TILs ve TSR'nin prognostik değerini netleştirmek için çok merkez katıımlı daha fazla sayıda safra kesesi kanser vakası üzerinde çalışmalar yapılabilir.

Anahtar Kelimeler: Safra kesesi kanseri, prognoz, stroma, tümör tomurcuklanması, tümörü infiltre eden lenfosit

Corresponding (illetişim): ilke Evrim SEÇiNTI, Assistant Professor, M.D., Hatay Mustafa Kemal University Faculty of Medicine Department of Pathology, Hatay, Turkey

E-mail (E-posta): ilkevrim@gmail.com

Received (Geliş Tarihi): 08.12.2021Ａccepted (Kabul Tarihi): 20.12.2021 


\section{INTRODUCTION}

Gallbladder cancer ( $\mathrm{GBC}$ ) is a rarely seen, however, the most common and aggressive malignancy of biliary tract. Its prognosis is extremely poor and its overall 5-year survival rate has not exceeded 5\%. ${ }^{[1]}$ American Cancer Society has reported 115,949 new cases and 84,695 deaths because of gallbladder cancer in 2020 worldwide. ${ }^{[2]}$ Its prognosis depends on tumor stage and the characteristics of the tumor cells, however, it has been encountered that the patients at the same stage might have very different prognosis. This fact indicates the need for determination of additional prognostic criteria.

Tumor microenvironment plays an important role in onset and progression of the cancer. Tumor budding (TB) is the tumor infiltration encountered as a single cell or a cluster $(<5$ cells) at the invasive tumor margin. TB has been accepted to be associated with presence of epithelial-mesenchymal transition and plays a role as an important prognostic factor in the clinical management of the cancer patients. ${ }^{[3]}$ It has been accepted as an important prognostic parameter particularly in the colorectal cancers as well as its popularity has progressively increased also in the other solid cancers. There is a limited number of studies that has investigated the impact of TB on prognosis in gallbladder cancer. ${ }^{[4-6]}$ Although, TB was shown to be associated with poor prognosis in these studies, further studies are needed to confirm its clinical effect.

Tumor stroma is also one of the factors that constitute the tumor microenvironment. In the recent years, tumor stroma has drawn attention as an independent prognostic factor in some solid tumors. Another component of tumor microenvironment is the tumor-infiltrating lymphocytes. The prognostic importance of tumor-infiltrating lymphocytes (TILs) have been demonstrated in some cancer types such as breast, ovarian and colon cancers. ${ }^{[7-10]}$

In the current literature, there is only a limited number of studies that has researched the impact of $\mathrm{TB}$, tumor stroma ratio (TSR) or TILs on prognosis in gallbladder carcinomas. [4,5,11,12] In the present study, it was aim to determine the relationship of TB, tumor stroma ratio (TSR) and tumorinfiltrating lymphocytes (TILs) with clinicopathological prognostic factors in gallbladder adenocarcinoma. Our study is the first that has investigated these three parameters concurrently in gallbladder carcinomas.

\section{MATERIALS AND METHODS}

\section{Patient selection}

The present study was approved by the local ethics committee (Date: 04.06.2020, Decision Number:23) and confirmed according to the ethical standards of the Helsinki Declaration.

A retrospective review was conducted on cholecystectomy specimens diagnosed with adenocarcinoma between 2010 and 2020 in our institution. Exclusion criteria were as follows: neoadjuvant therapy, histopathological diagnosis other than adenocarcinoma (e.g., adenosquamous carcinoma, neuroendocrine carcinoma and undifferentiated carcinoma) and/or unavailability of the archival haematoxylin and eosin (H\&E) slides for review. As a consequence, 30 patients were included in the present study. The clinical and followup information was obtained from the electronic medical records.

\section{Histopathological analysis}

All archival H\&E slides of the resection specimens were reexamined under the Olympus BX51 microscope (Olympus, Tokyo, Japan) by two pathologists blinded to clinical information. All pathological parameters including histological differentiation grade, invasion depth, resection margin status, lymph node (LN) metastasis, lymphovascular invasion $(\mathrm{LVI})$, perineural invasion (PNI), surgical margin and distant metastasis were re-evaluated. Tumor staging was performed according to the eighth edition of the AJCC Staging Manual (pTNM, AJCC 8th Edition). ${ }^{[13]}$

TB, TSR and TILs were evaluated by two independent pathologists (IES, DG) blinded to clinicopathological data. In the case of inconsistency between the conclusions of the two pathologists, the results were evaluated by a third independent pathologist (TO) blinded to the clinicopathological data and the conclusions of the other researchers. The final outcome was approved and recorded by consensus of at least two pathologists.

\section{Assessment of tumor budding}

The following steps were followed for assessment of TB according to the ITBCC guideline: ${ }^{[14]}$

The field with the highest density of "hotspot" peritumoral budding in the 10x medium power field (10Xobjective) in the hematoxylin and eosin (H\&E) slides was selected.

Following, tumor buds were counted using a 20X objective.

The count was normalized to a field measured as $0.785 \mathrm{~mm}^{2}$ (counted tumor buds/normalization factor adjusted to the microscope). The features of the used microscope were as follows: Eyepiece FN Diameter: 22 mm, Specimen Area: 0.950 $\mathrm{mm}^{2}$, Normalization Factor: 1.210.

Tumor buds were counted in a field of $0.785 \mathrm{~mm}^{2}$ and scored as TB score1 (0-4 buds), TB score2 (5-9 buds) and TB score3 ( $\geq 10$ buds).

\section{Assessment of tumor stroma ratio}

All tumor slides were scanned with a $4 \mathrm{X}$ objective lens to determine the field with the highest tumor depth. TSR was analyzed using a 10X objective lens. Only the fields containing both stroma and tumor within the field of view were scored to avoid scoring of the peripheral regions of the tumor margin. Since stroma-rich fields have been associated with worse prognosis, these fields were accepted to be determinant in the cases with heterogeneous TSR. In TSR, stromal ratio higher than $50 \%$ accepted to be stroma-rich while stromal ratio lower than $50 \%$ was considered to be stroma-poor. ${ }^{[11]}$ 


\section{Assessment of tumor-infiltrating lymphocytes}

TILs were assessed semiquantitatively using the criteria defined by Salgado et al. All the tumor slides were scanned by 100 -fold and 200 -fold magnification (objective $\times 10, \times 20$ ) and mean stromal TILs (lymphocytes and plasma cells) were recorded as a continuous variable (also including the TILs on the margin of infiltration). ${ }^{[7]}$

\section{Statistical Analysis}

Our study data were analyzed using Social Sciences V.21.0 software package (SPSS Inc, Armonk, NY, US). The continuous variables were expressed as mean value and standard deviation while frequency and percentage values were given for the categorical variables. The normality was tested using Shapiro Wilk test. Chi-Square tests (Yatescorrected, likelihood ratio) were used in the analysis of the relationships between the categorical variables. Besides, Goodman and Kruskal's Gamma analysis results were taken into consideration regarding the relationships between ordinal variables. ANOVA and Kruskal Wallis tests were applied for comparison of the continuous variables. The prognostic appropriateness of TILs was assessed by means of receiver operating characteristic (ROC) analysis selecting death as the status variable and the optimal cut-off value was calculated using the Youden index for maximum of specificity and sensitivity. ${ }^{[8]}$ Accordingly, $\leq 10 \%$ TILs and $>10 \%$ TILS values were grouped as low and high, respectively. Kaplan-Meier curves and log-rank test were applied to test the differences between overall survival duration (OS) of the variables TB, TSR and TILs. Raw hazard ratios and adjusted risks for the variables TB score, TSR and TILs were analyzed by Cox regression analysis. $A \quad p<0.05$ value was accepted to be statistically significant.

\section{RESULTS}

Totally 30 cases were included in the study. The study group comprised of 11 males (36.7\%) and 19 females (63.3\%). The mean \pm SD age of the patients was $69.27 \pm 10.49$ years. The histological grades of the tumor were low, moderate and high in $6(20 \%), 19(63.3 \%)$ and $5(16.7 \%)$ cases, respectively. LVI and perineural invasion were detected in $19(63.3 \%)$ and 18 (60\%) cases, respectively. Totally $3(10 \%), 10(33.3 \%), 16$ (53.3\%) and 1 (3.3\%) cases were evaluated as pT1, pT2, pT3 and pT4, respectively. The lymph node involvement stages were NO and $\mathrm{N} 1+\mathrm{N} 2$ in 21 (70\%) and 9 (30\%) cases, respectively. Liver invasion at the time of diagnosis was present in 14 (46.7 \%) cases. The distant metastasis at the time of diagnosis was identified in $12(40.0 \%)$ cases (Table 1). The median follow-up period was $525.2 \pm 700$ days. Totally 10 (33.3\%) cases survived whereas 17 (56.7\%) cases died, 3 cases could not be followed-up.

In this study, 13 (43.33\%) tumors were TB score 1 (Figure 1A) and 9 (30\%) tumors were score 2 (Figure 1B) and 8 (26.67\%) tumors were score 3 (Figure 1C). High TB score was found significantly associated with higher histological grade $(p=0.008)$, higher $p$ T stage, LVI $(p=0.038), L N$ metastasis $(p=0.046)$ and distant metastasis $(p=0.036)$. TB score showed no significant relationship with age $(p=0.937)$, gender $(p=0.597)$, presence of PNI $(p=0.104)$, surgical margin positivity $(p=0.813)$, liver invasion $(p=0.293)$, TSR $(p=0.461)$ and TILs $(p=0.490)$ (Table 2). High TB score was encountered to be associated with a shorter OS $(p<0.001)$. Mean OS of the patients with low TB score was 1733.4 days [95\%Cl: 1048.02418.8] whereas that of the patients with moderate and high TB scores were 283.8 days [95\% Cl: 136.5-431.0] and 93.1 days [95\%Cl:45.5-140.8], respectively (Figure 2).

The AUC (area under curve) value of TILs for a cutoff point of $10 \%$ was calculated as 0.80 (specificity: $80 \%$, sensitivity: 70\%, p:0.01) (Figure 3). In this study, 14 (46.67) tumors were TILS $>10 \%$ (Figure 4A) and 16 (53.33\%) tumors were TILS $\leq 10 \%$. (Figure 4B). No significant relationship of TILs was found with gender $(p=0.631)$, PNI $(p=0.156)$, liver invasion $(p=1.000)$, $p T$ stage $(p=0.716)$ and lymph node metastasis $(p=0.440)$. High TILs were significantly associated with lower histological grade ( $p=0.004)$, less LVI $(p=0.029)$, fewer distant metastasis $(p=0.021)$ and lower TSR $(p=0.008)$ (Table 3). Mean OS of the patients with low TILs was 366.4 days [95\%Cl:164.2-568.5] whereas that of the patients with high TILs was 1516.4 days [95\%Cl: 777.2-2255.5] (p:0.051) (Figure 2).

\begin{tabular}{|c|c|c|c|}
\hline Variables & Categories & n (\%) & Mean \pm SD \\
\hline \multirow{2}{*}{ Gender } & Female & $19(63.33 \%)$ & \\
\hline & Male & $11(36.67 \%)$ & \\
\hline \multirow{3}{*}{ Grade } & 1 & $6(20.0 \%)$ & \\
\hline & 2 & $19(63.33 \%)$ & \\
\hline & 3 & $5(16.67 \%)$ & \\
\hline \multirow{2}{*}{$\begin{array}{l}\text { Lymphovascular } \\
\text { invasion }\end{array}$} & Absent & $11(36.67 \%)$ & \\
\hline & Present & $19(63.33 \%)$ & \\
\hline \multirow{2}{*}{ Perineural invasion } & Absent & $12(40.0 \%)$ & \\
\hline & Present & $18(60.0 \%)$ & \\
\hline \multirow{2}{*}{ Surgical margin } & Negative & $20(66.67 \%)$ & \\
\hline & Positive & $10(33.33 \%)$ & \\
\hline \multirow{2}{*}{ Liver invasion } & Absent & $16(53.33 \%)$ & \\
\hline & Present & $14(46.67 \%)$ & \\
\hline \multirow{4}{*}{ pT stage } & 1 & $3(10.0 \%)$ & \\
\hline & 2 & $10(33.33 \%)$ & \\
\hline & 3 & $16(53.33 \%)$ & \\
\hline & 4 & $1(3.33 \%)$ & \\
\hline \multirow{2}{*}{$\mathrm{N}$ stage } & 0 & 21 (70.0\%) & \\
\hline & $1+2$ & $9(30.0 \%)$ & \\
\hline \multirow{2}{*}{ M stage } & 0 & $18(60.0 \%)$ & \\
\hline & 1 & $12(40.0 \%)$ & \\
\hline \multirow{2}{*}{ TSR } & Stroma $<\% 50$ & $17(56.67 \%)$ & \\
\hline & Stroma $>\% 50$ & $13(43.33 \%)$ & \\
\hline \multirow{3}{*}{ TB score } & 1 & $13(43.33 \%)$ & \\
\hline & 2 & $9(30.0 \%)$ & \\
\hline & 3 & $8(26.67 \%)$ & \\
\hline Age & & & $69.27 \pm 10.49$ \\
\hline TILs & & & $22.67 \pm 22.74$ \\
\hline
\end{tabular}




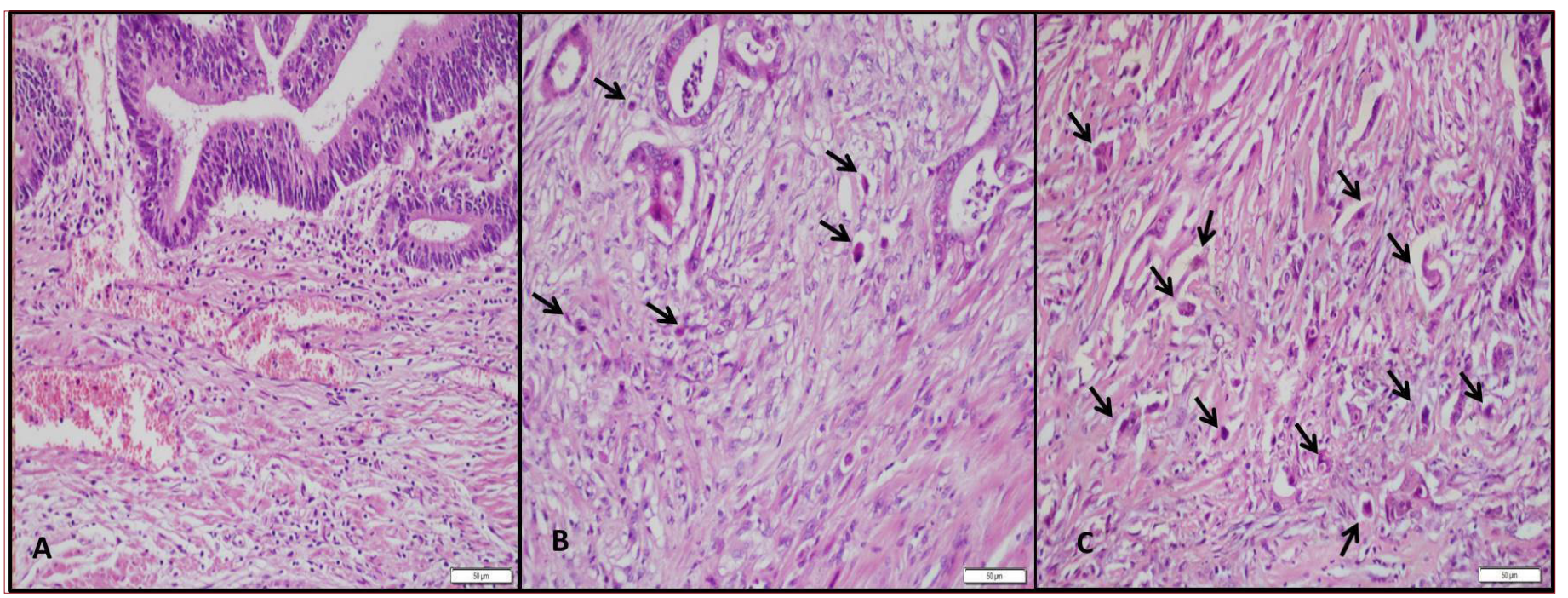

Figure 1. Tumor budding score 1 (A), score 2 (B) and score 3 (C) are seen in hematoxylin-eosin stained slides (Buds are indicated by arrows). H.Ex20

Table 2. Relationship between tumor budding score and clinicopathological findings

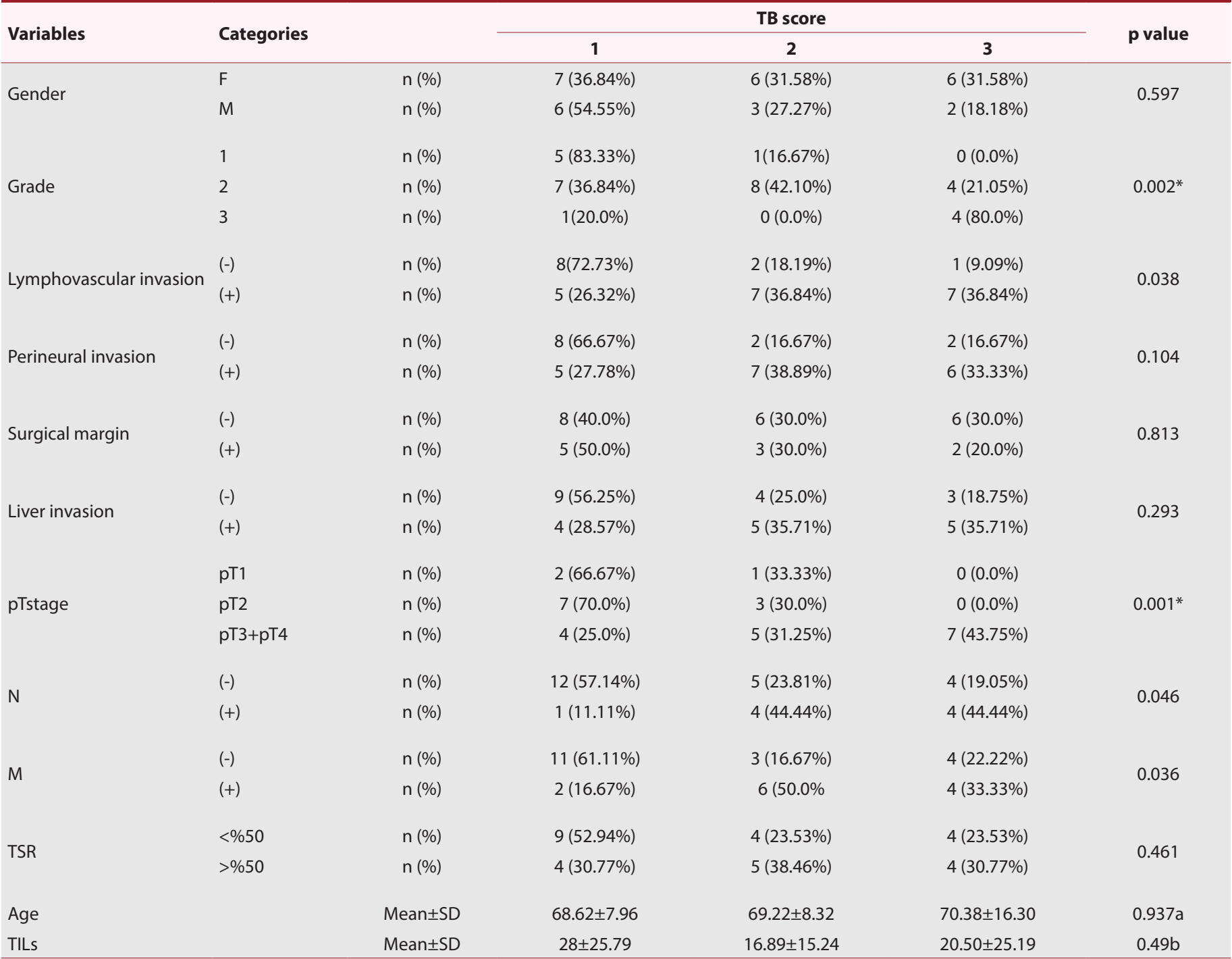

TB: Tumor budding, TSR: Tumor stroma ratio, TILs: Tumor-infiltrating lymphocytes, N: Lymph node metastasis, M: Distant metastasis, *Godman Kruskal Gamma results are given for Grade and pT stage (coefficients 0.762 and 0.742 , respectively). aANOVA test. bKruskal Wallis test. Chi-square (likelihood ratio) test results were given for other analyzes 


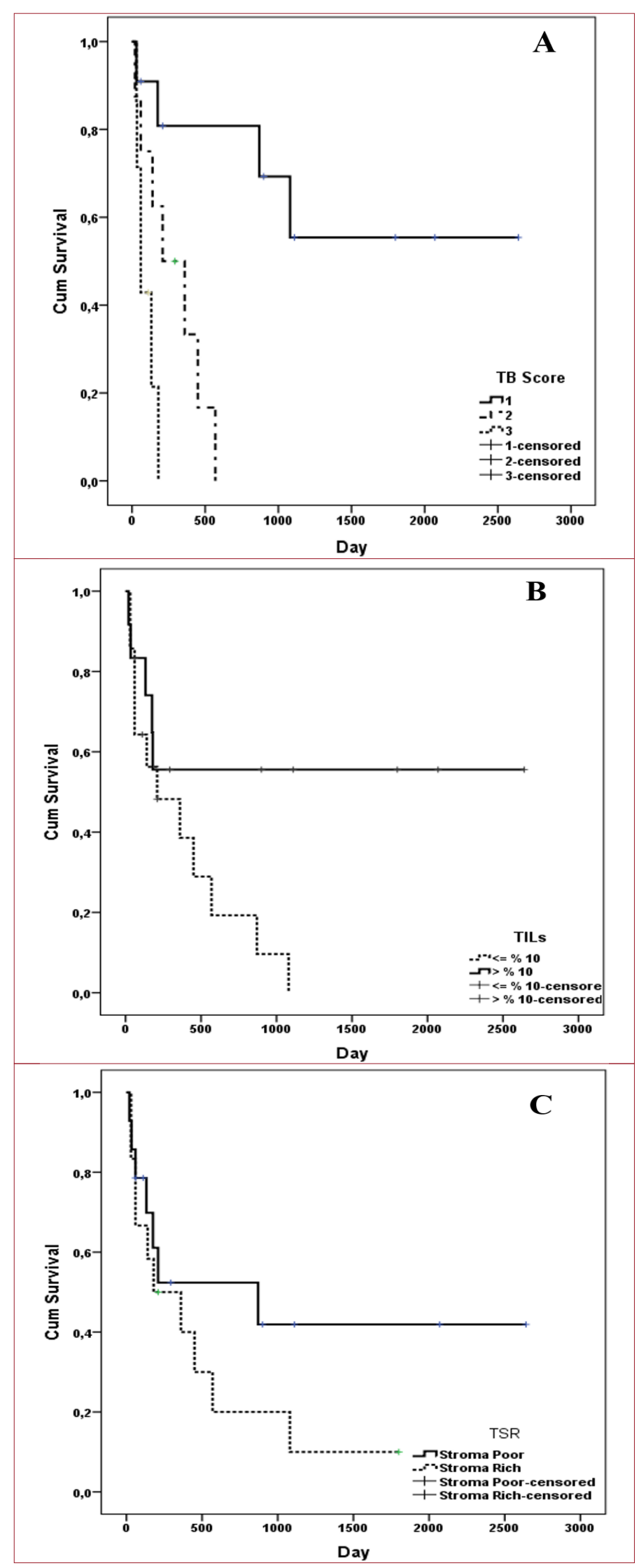

Figure 2. Kaplan-Meier curves of TB score (A), TILs (B), and TSR (C)
In the present study, 17 (56.67\%) tumors were stroma poor (Figure 5A) and 13 (43.33\%) tumors were stroma rich (Figure 5B). Increased TSR ( $\% 50$ stroma: stroma rich) was found associated with higher histological grade $(p=0.015)$ and increased metastasis frequency $(p=0.013)$. No significant relationship of TSR with gender ( $p=1.000), \mathrm{LVI}(p=0.708), \mathrm{PNI}$ $(p=0.599)$, liver invasion $(p=0.749)$, pT stage $(p=0.845)$, lymph node metastasis $(p=0.630)$ and surgical margin $(p=1.000)$ was detected (Table 3). Stroma ratio demonstrated no significant impact on OS $(p=0.239)$. The patients with TSR $<50 \%$ (stromapoor) had a mean of OS 1250.8 days [95\%Cl:559.9-1941.7] whereas that duration of the patients with TSR $>50 \%$ (stromarich) was 467.7 days [95\%Cl:146.9-788.4] (Figure 2).

The univariate cox regression analysis of TB, TSR and TILs variables for survival status revealed that TSR and TILs posed no risk individually $(p=0.250$ and $p=0.063$, respectively). However, TB score was found significant $(p=0.005)$. The multivariate evaluation of TB score concurrently with TILs revealed that TB score, particularly TB score3, increased the mortality risk by approximately 21 -fold (95\%Cl: $3.25-137.82$, $\mathrm{p}=0.001)$. However, it was determined that TILs posed no risk in the multivariate evaluation $(p=0.216)$.

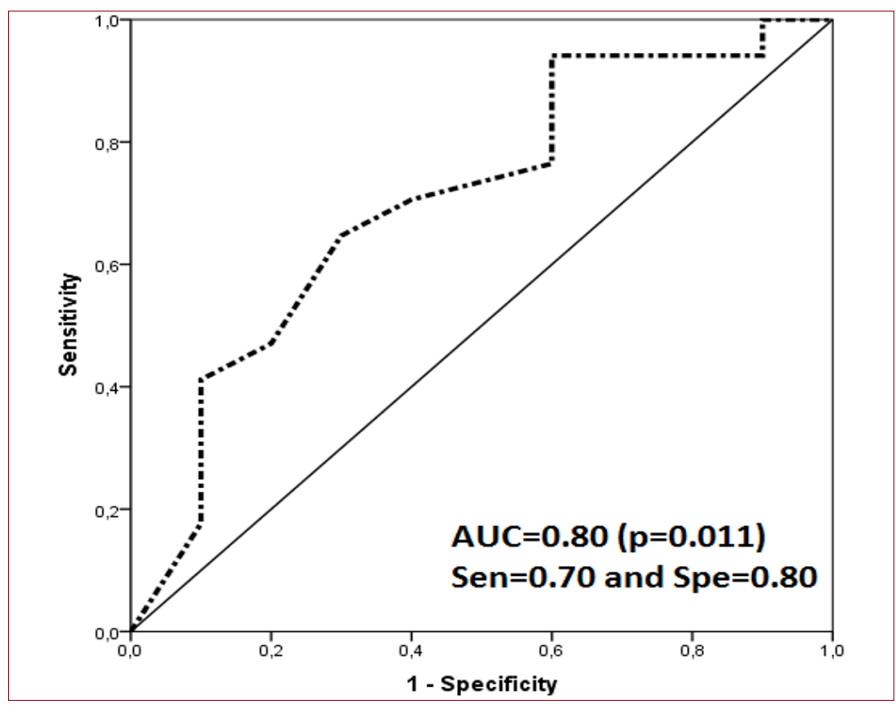

Figure 3. ROC curve relative to TILs values

\section{DISCUSSION}

Tumor cells form intact clusters using intercellular adhesion mechanisms in the first stages of carcinogenesis and they usually maintain this adhesion until undergoing sufficient dedifferentiation. ${ }^{[15,16]}$ EMT (Epithelial-Mesenchymal Transition) is a phenomenon that tumor cells lose their cohesive properties and develop a tendency of separation and migration. ${ }^{[17]}$ After EMT, tumor cells may enter the surrounding lymphovascular structure by detaching from the primary mass and metastasize towards distant organs. TB is accepted as an important histopathological parameter of EMT. ${ }^{[18,19]}$ 


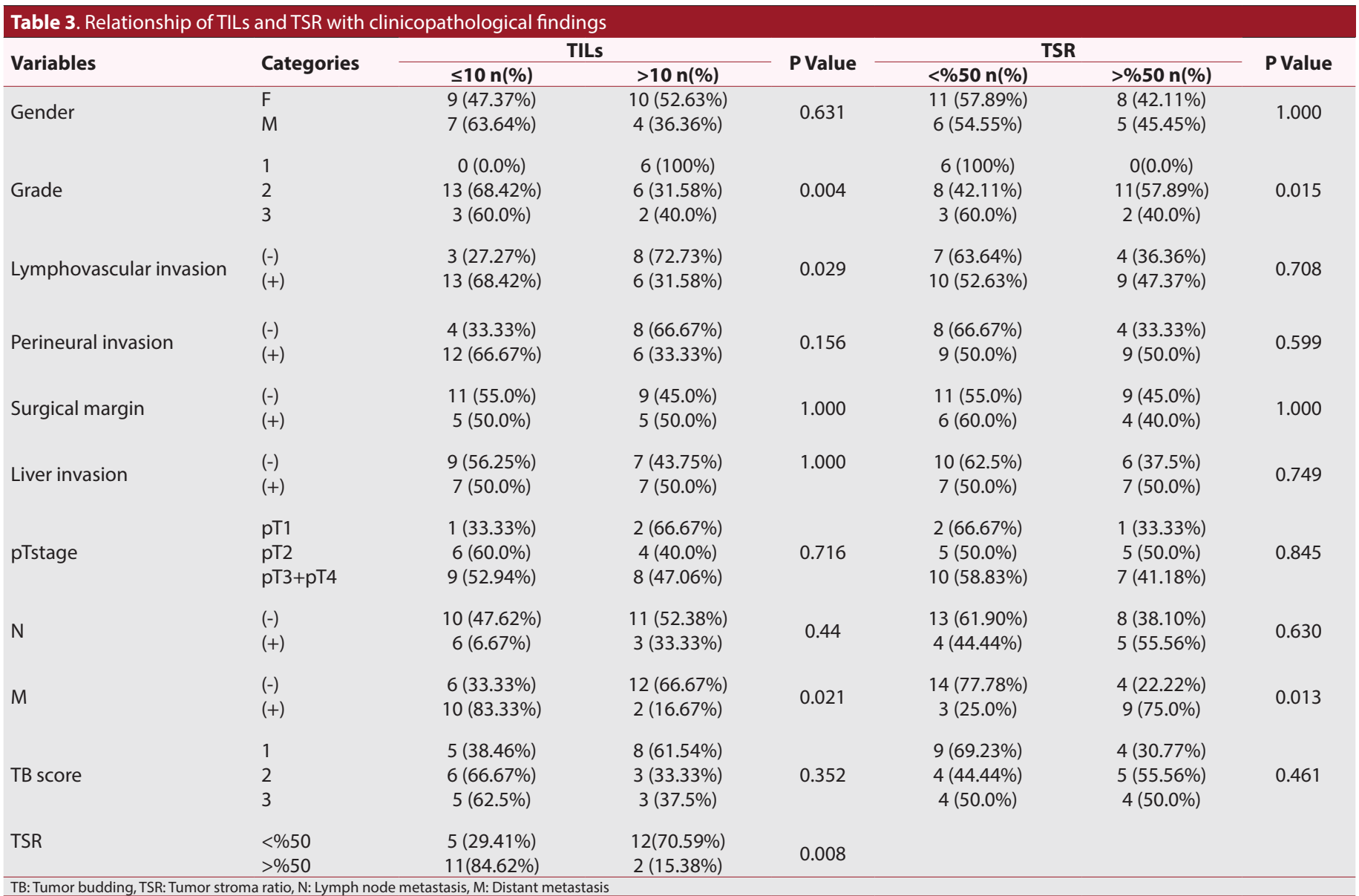

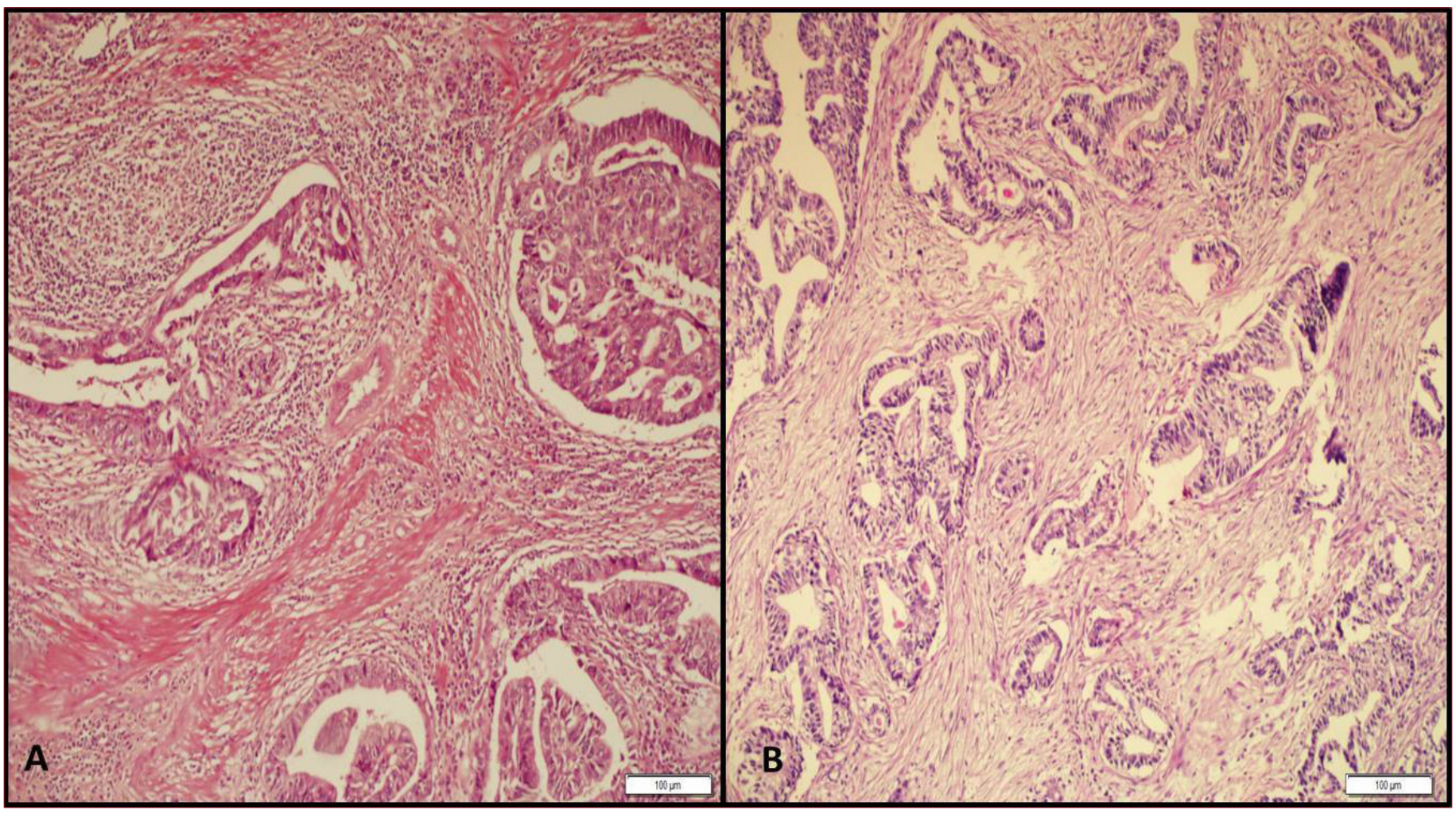

Figure 4. TILS $>10 \%$ (A) and TILS $\leq 10 \%$ (B) are seen in hematoxylin-eosin stained slides. H.Ex10. 


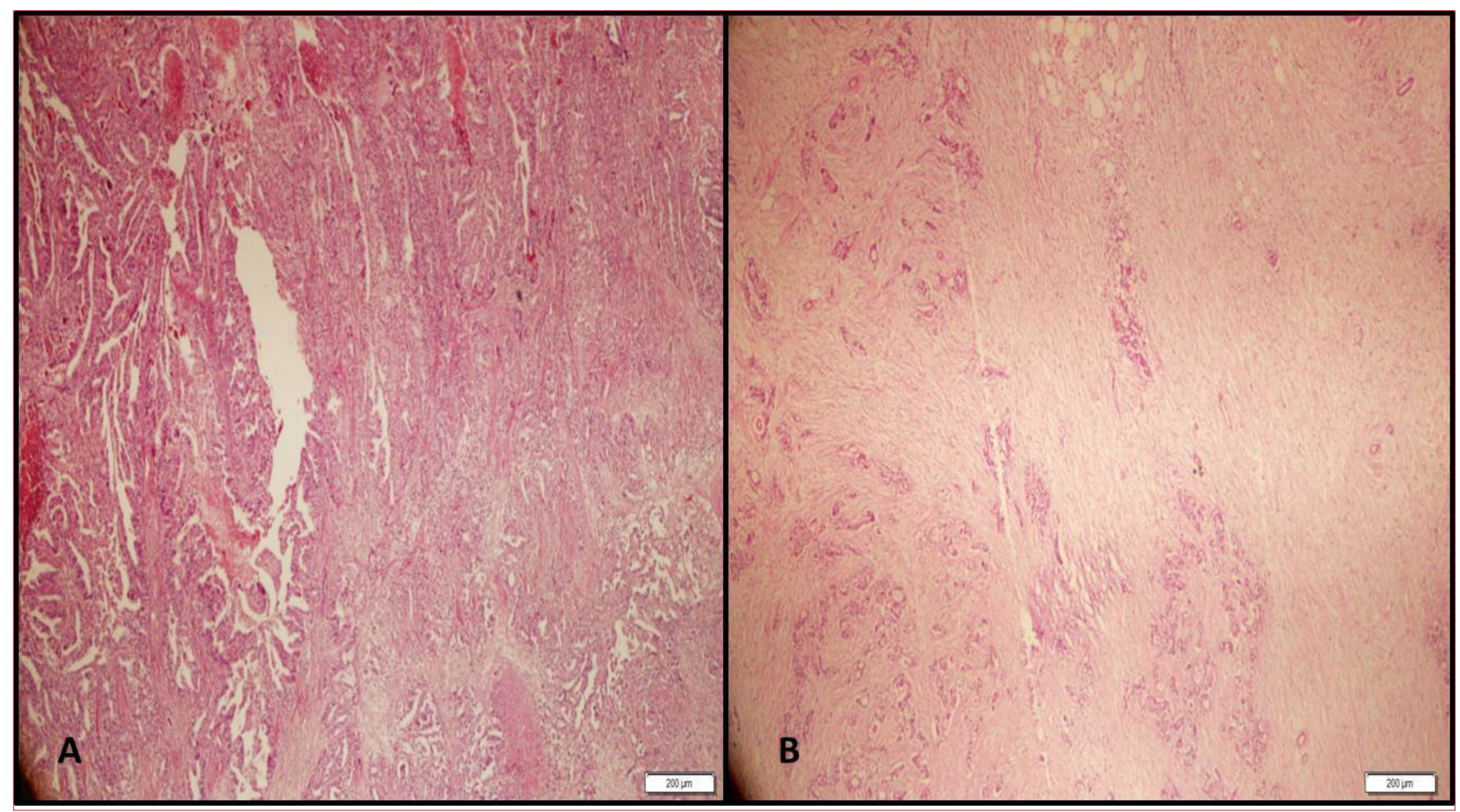

Figure 5. Tumor stroma ratio $<50 \%$ (stroma poor) $(\mathrm{A})$ and tumor stroma ratio $>50 \%$ (stroma rich) $(\mathrm{B})$ are seen in hematoxylin-eosin stained slides. H.Ex4

TB has been investigated in many cancer types such as primarily CRC (colorectal carcinoma), pancreatic ductal adenocarcinoma, oral squamous cell carcinoma, lung (adenocarcinoma+ squamous cell carcinoma), endometrial cancer, breast, stomach and esophageal cancers. ${ }^{[2]}$ It has been suggested that TB was associated with poor prognosis in most of those cancer types. However, in the present time, routine reporting of tumor budding scores have been recommended only in the current protocols related with CRC reporting. The relationship of high tumor budding score with aggressive tumor characteristics such as more advanced pT, pN and AJCC stages, lymphovascular and perineural invasions, distant metastasis and local tumor recurrence in colorectal cancer has been demonstrated in many studies of the literature. ${ }^{[8,9,20-24]}$ In the study of Kim et al. conducted on 78 GBC patients; a higher TB score was found associated with a poorer histological differentiation, a higher PT stage, presence of LN metastasis as well as lymphatic, venous or perineural tumor invasion. ${ }^{[4]}$ Similarly, Kai et al. have also reported that presence of TB was significanly associated with advanced $T$ stage, $L N$ metastasis and venous invasion in $\mathrm{GBC}^{[5]}$ In our study, similarly with literature, high TB score was determined to be significantly associated with a higher histological grade $(p=0.008)$, a higher $p T$ stage, $L V I(p=0.038), L N$ metastasis $(p=0.046)$ and distant metastasis $(p=0.036)$. High TB score was encountered to be associated with a shorter survival duration $(p<0.001)$. The patients with a low TB score had a mean OS of 1733.4 days [95\% Cl: 1048.0-2418.8] whereas those with moderate and high TB scores had mean OS of 283.8 days [ $95 \%$ Cl: 136.5-431.0] and 93.1 days [95\% Cl: 45.5-140.8], respectively.
It was observed that particularly TB score-3 increased mortality risk by approximately 21 -fold ( $95 \% \mathrm{Cl}: 3.25-137.82, \mathrm{p}=0.001$ ). Our results supported that TB was a significant prognostic parameter of GBC.

In the recent years, the effective role of immunotherapies in the cancer treatment has drew attention in the experimental and clinical studies. The importance of the determination of the reliable bioindicators is clearly obvious for selection of the patients with the highest probability of responsiveness to the immunotherapeutic agents. By these improvements, the importance of the evaluation of TILs has increased as the prognostic and treatment response predictivefactors in various cancer types. ${ }^{[25]}$ The increased rates of TILs has been associated with good prognosis in many different cancer types..$^{[7,26-28]}$ There is a limited number of studies that have investigated the effect of TILs in GBC and these studies have found that increased TILs was associated with better prognosis. ${ }^{[12,29]}$ In this study, TILs were not significantly associated with gender, PNI, liver invasion, pT stage, and lymph node metastasis, but higher TILs were associated with lower histological grade $(p=0.004)$, less LVI $(p=0.029)$, less distant metastasis $(p=0.021)$ and low TSR $(p=0.008)$. In addition, it can be considered that the prognosis of the patients with TILs value $\leq 10 \%$ may worsen according to OS. The fact that TILs are not significantly associated with liver invasion and advanced PT stage, which are known as indicators of poor prognosis, seems to weaken the prognostic importance of TILs. This may be resulting from the fact that we evaluated TILs by only H\&E stained slides differently from Patil et al. ${ }^{[12]}$ and Lin et al. ${ }^{[29]}$ This outcome suggests us that TILs 
are a strong candidate to be a prognostic parameter of $\mathrm{GBC}$, however, they should be supported by immunohistochemical studies such as CD3 and CD8.

TB is strongly associated with the stroma and immune system components that make up the tumor microenvironment. ${ }^{[3]}$ The answer of the question that TB is a consequence of tumor microenvironment or the changes in the tumor microenvironment still remains unknown. Therefore, the relationship between TB and tumor microenvironment is interesting. Many studies in the literature have shown that TB was inversely proportional with peritumoral inflammation which is an indicator of tumor microenvironment. ${ }^{[20,23,24]}$ However, Lang-Schwarz et al. have advocated that tumor budding is independent from inflammation. ${ }^{[9]}$ It was found in the present study supporting the results of Lang-Schwarz et al. that there was no relationship between TB and TILs $(p=0.352)$. Similarly, no relationship was detected also between TB and TSR $(p=0.461)$, however, this outcome is not adequate to conclude that stroma has no impact on TB. Various stromal factors and pathways may influence TB independently from stroma ratio.

The increased tumor stroma ratio has been associated with worse survival in a series of solid cancer types including GBC. ${ }^{[11,30-32]}$ However, it is not clear whether the impact of increased TSR on survival is independent from the host inflammatory responses and other components of tumor microenvironment. The relationship between tumor stroma, host and tumor characteristics has not been clarified. Li et al. have reported in their study on 51 GBC cases that TSR had an effect on OS, however, it had no independent prognostic effect on OS. It has been stated in the same research that TSR was not associated with other tumor-related parameters except pTstage. ${ }^{[1]}$ It was determined in the present study that stroma-rich tumors had higher histological grade $(p=0.015)$ and less TILs $(p=0.008)$ while they metastasized more frequently $(p=0.013)$. However, TSR had no relationship with other prognostic parameters of tumor (pT stage, LVI, $\mathrm{PNI}$, liver invasion, TB score, lymph node metastasis) and demonstrated no effect on OS ( $p=0.239$ ).

The limitations of our study were low number of cases and lack of supporting molecular studies. However, we conclude that researches conducted on limited number of case series also should be reported in the literature since gallbladder cancer is a rarely seen cancer type.

\section{CONCLUSION}

TB can be used as a new prognostic biomarker in GBCs due to its simple and low cost to determine and also its effectiveness in determining the prognosis. We have concluded that it is early to recommend TILs and TSR as the prognostic parameters in GBCs. In the future, further studies can be conducted on a larger number of GBC cases with a multicenter participation to clarify the prognostic value of TILs and TSR.

\section{ETHICAL DECLARATIONS}

Ethics Committee Approval: The present study was approved by Hatay Mustafa Kemal University Board of Ethics on Noninvasive Clinical Human Studies Ethics Committee (Date: 04.06.2020, Decision Number:23).

Informed Consent: Because the study was designed retrospectively, no written informed consent form was obtained from patients.

Referee Evaluation Process: Externally peer-reviewed.

Conflict of Interest Statement: The authors have no conflicts of interest to declare.

Financial Disclosure: The authors declared that this study has received no financial support.

Author Contributions: All of the authors declare that they have all participated in the design, execution, and analysis of the paper, and that they have approved the final version.

\section{REFERENCES}

1. Duffy A, Capanu M, Abou-Alfa GK, et al. Gallbladder cancer (GBC): 10-year experience at Memorial Sloan-Kettering Cancer Centre (MSKCC). J Surg Oncol 2008; 98(7):485-9.

2. Sung H, Ferlay J, Siegel RL, et al. Global Cancer Statistics 2020: GLOBOCAN Estimates of Incidence and Mortality Worldwide for 36 Cancers in 185 Countries. CA Cancer J Clin 2021;71(3):209-49.

3. Lugli A, Zlobec I, Berger MD, Kirsch R, Nagtegaal ID. Tumour budding in solid cancers. Nat Rev Clin Oncol 2021;18(2):101-15.

4. Kim HN, Lee SY, Kim BH, Kim CY, Kim A, Kim H. Prognostic value of tumor budding in gallbladder cancer: application of the International Tumor Budding Consensus Conference scoring system. Virchows Arch 2021;478(6):1071-8.

5. Kai K, Kohya N, Kitahara K, et al. Tumor budding and dedifferentiation in gallbladder carcinoma: potential for the prognostic factors in T2 lesions. Virchows Arch 2011;459(4):449-56.

6. Okubo S, Mitsunaga S, KatoY, et al. The prognostic impact of differentiation at the invasive front of biliary tract cancer. J Surg Oncol 2018;117:1278-87.

7. Salgado R, Denkert C, Demaria S, et al.; International TILs Working Group 2014. The evaluation of tumor-infiltrating lymphocytes (TILs) in breast cancer: recommendations by an International TILs Working Group 2014. Ann Oncol 2015;26(2):259-71.

8. Lang-Schwarz C, Melcher B, Haumaier F, et al. Budding and tumorinfiltrating lymphocytes - combination of both parameters predicts survival in colorectal cancer and leads to new prognostic subgroups. Hum Pathol 2018;79:160-7.

9. Lang-Schwarz C, Melcher B, Haumaier F,et al. Budding, tumor-infiltrating lymphocytes, gland formation: scoring leads to new prognostic groups in World Health Organization low-grade colorectal cancer with impact on survival. Hum Pathol 2019;89:81-89.

10. Li J, Wang J, Chen R, Bai Y, Lu X. The prognostic value of tumor-infiltrating T lymphocytes in ovarian cancer. Oncotarget 2017;8(9):15621-31.

11. Li H, Yuan SL, Han ZZ, et al. Prognostic significance of the tumor-stroma ratio in gallbladder cancer. Neoplasma 2017;64(4):588-93.

12. Patil PA, Lombardo K, Cao W. Immune Microenvironment in Gallbladder Adenocarcinomas. Appl Immunohistochem Mol Morphol 2021;29:557-63.

13. Amin MB, Edge S, Greene F, et al. (Eds.). AJCC Cancer Staging Manual (8th edition). Springer International Publishing: American Joint Commission on Cancer; 2017 [cited 2016 Dec 28]

14. Lugli A, Kirsch R, Ajioka Y, et al. Recommendations for reporting tumor budding in colorectal cancer based on the International Tumor Budding Consensus Conference (ITBCC) 2016. Mod Pathol 2017;30(9):1299-311.

15. Te Boekhorst V, Friedl P. Plasticity of Cancer Cell Invasion-Mechanisms and Implications for Therapy. Adv Cancer Res 2016;132:209-64. 
16. Friedl $\mathrm{P}$, Alexander S. Cancer invasion and the microenvironment: plasticity and reciprocity. Cell. 2011 Nov 23;147(5):992-1009.

17. Lu W, Kang Y. Epithelial-Mesenchymal Plasticity in Cancer Progression and Metastasis. Dev Cell 2019;49(3):361-74.

18. Grigore AD, Jolly MK, Jia D, Farach-Carson MC, Levine H. Tumor Budding: The Name is EMT. Partial EMT. J Clin Med 2016;5(5):51.

19. Li H, Xu F, Li S, Zhong A, Meng X, Lai M. The tumor microenvironment: An irreplaceable element of tumor budding and epithelial-mesenchymal transition-mediated cancer metastasis. Cell Adh Migr 2016;10(4):434-46.

20. Zlobec I, Dawson HE, Blank A, et al. Are tumour grade and tumour budding equivalent in colorectal cancer? A retrospective analysis of 771 patients. Eur J Cancer 2020;130:139-45.

21. Zlobec I, Berger MD, Lugli A. Tumour budding and its clinical implications in gastrointestinal cancers. Br J Cancer 2020;123(5):700-8.

22. Rieger G, Koelzer VH, Dawson HE, et al. Comprehensive assessment of tumour budding by cytokeratin staining in colorectal cancer. Histopathology 2017;70(7):1044-51.

23. Fujiyoshi K, Väyrynen JP, Borowsky J, et al. Tumour budding, poorly differentiated clusters, and T-cell response in colorectal cancer. EBioMedicine. 2020;57:102860.

24. Dawson $H$, Galuppini $F$, Träger $P$, et al. Validation of the International Tumor Budding Consensus Conference 2016 recommendations on tumor budding in stage I-IV colorectal cancer. Hum Pathol 2019;85:145-51.

25. Hendry S, Salgado R, Gevaert T, et al. Assessing Tumor-Infiltrating Lymphocytes in Solid Tumors: A Practical Review for Pathologists and Proposal for a Standardized Method from the International ImmunoOncology Biomarkers Working Group: Part 2: TILs in Melanoma, Gastrointestinal Tract Carcinomas, Non-Small Cell Lung Carcinoma and Mesothelioma, Endometrial and Ovarian Carcinomas, Squamous Cell Carcinoma of the Head and Neck, Genitourinary Carcinomas, and Primary Brain Tumors. Adv Anat Pathol 2017;24(6):311-35.

26. Hwang C, Lee SJ, Lee JH, et al. Stromal tumor-infiltrating lymphocytes evaluated on H\&E-stained slides are an independent prognostic factor in epithelial ovarian cancer and ovarian serous carcinoma. Oncol Lett 2019;17(5):4557-65.

27. Weiss SA, Han SW, Lui K, et al. Immunologic heterogeneity of tumorinfiltrating lymphocyte composition in primary melanoma. Hum Pathol 2016;57:116-25.

28. Rozek LS, Schmit SL, Greenson JK, et al. Tumor-Infiltrating Lymphocytes, Crohn's-Like Lymphoid Reaction, and Survival From Colorectal Cancer. J Natl Cancer Inst 2016;108(8):djw027.

29. Lin J, Long J, Wan X, et al. Classification of gallbladder cancer by assessment of CD8+ TIL and PD-L1 expression. BMC Cancer 2018;18(1):766.

30. Mesker WE, Junggeburt JM, Szuhai K, et al. The carcinoma-stromal ratio of colon carcinoma is an independent factor for survival compared to lymph node status and tumor stage. Cell Oncol. 2007;29(5):387-98.

31. Park JH, Richards CH, McMillan DC, Horgan PG, Roxburgh CSD. The relationship between tumour stroma percentage, the tumour microenvironment and survival in patients with primary operable colorectal cancer. Ann Oncol 2014;25(3):644-51.

32. Dekker TJ, van de Velde CJ, van Pelt GW, et al. Prognostic significance of the tumor-stroma ratio: validation study in node-negative premenopausal breast cancer patients from the EORTC perioperative chemotherapy (POP) trial (10854). Breast Cancer Res Treat 2013;139(2):371-9. 